\title{
MECHANICAL, MORPHOLOGICAL AND THERMAL PROPERTIES OF NANO-BORON NITRIDE TREATED WOOD MATERIALS
}

\author{
Deniz Aydemir ${ }^{1, \star}$, Busra Civit, Mizgin Alsan ${ }^{1}$, Ahmet Can ${ }^{1}$, Huseyin Sivrikaya ${ }^{1}$, \\ Gokhan Gunduz', Alice Wang ${ }^{2}$
}

\begin{abstract}
Thermal instability is the one of the most important disadvantages of wood since it begins to decompose at a low temperature $\left(>110^{\circ} \mathrm{C}\right)$. Many scientists, past and present, have conducted studies aimed at improving the thermal stability of wood. The aim of this study was to impregnate wood with nano-sized boron nitride (NBN) to improve its thermal stability and to investigate the changes in the properties of Scots pine (Pinus sylvestrist), Ash (Fraxinus exelsior), and Iroco (Chlorophora excelsa) woods after the impregnation. The effects of the impregnation with NBN also were investigated on the heat-treated woods. The impregnation was conducted with using full-cell method in a chamber under a pressure of $0.6 \mathrm{MPa}$ for $1 \mathrm{~h}$. Densities at $0 \%$ and $12 \%$ moisture content (MC), mechanical properties, color changes, thermal stability, and scanning electron microscopy (SEM/EDAX) analysis were determined. The test results showed that the impregnation of wood with NBN increased generally the flexural strength and elasticity of modulus at bending, but the NBN impregnation decreased generally the compression strength except for ACI, ATWI, IC, and ICI. It was also determined that the changes in density and color were statistically different after the impregnation. According to the SEM/EDAX results, deposits of nano-sized boron nitride were found inside the cell wall and on the pits. But the deposits were also determined in inside structure of the wood with EDAX analysis. Thermal stability in $\mathrm{T}_{10 \%}$ and $\mathrm{T}_{50 \%}$ of wood was found to improve after the impregnation with NBN. TG/DTG and DTA values for some samples were found to fluctuate due to the heterogeneous dispersion of the NBN in the wood.
\end{abstract}

Keywords: Impregnation, nanoboron nitride, nano-sized particles, thermal stability, wood.

\section{INTRODUCTION}

Wood is a renewable material, and it has many applications, such as furniture, outside sidings, pulp/paper, and wood panels. Although there are many application areas, wood is easily degraded by sunlight, moisture, and elevated temperatures due to its organic structure. Degradation of the chemical structure and deterioration of the surface wood are the primary reasons for color changes in wood (Rosu et al. 2010). One of the most important challenges is the thermal decomposition of the components of wood, e.g., cellulose, lignin, and hemicellulose, at the low temperatures $\left(100-150^{\circ} \mathrm{C}\right)$. Therefore, woods have different degradation points depending on their specific chemical compositions. Cellulose, a major component of wood, has a highly crystalline structure, which makes it thermally stable. However, other major structural components of wood, such as hemicelluloses and lignin, have amorphous structures and start to degrade at low temperatures due to the presence of acetyl groups (Poletto et al. 2012, Shebani et al. 2008, Hill 2006, Bourgois et al. 1984, Nassar and Mackay 1984).

${ }^{1}$ Bartin University, Faculty of Forestry, Department of Forest Industrial Engineering, Bartin, Turkey.

${ }^{2}$ Lulea University of Technology, Wood Technology, Skellefteå, Sweden.

•Corresponding Author: denizaydemir@bartin.edu.tr

Received: 01.10.2014 Accepted: 02.10.2015 
Nano-sized particles offer the opportunity to obtain desirable properties in organic materials. The properties of wood such as its mechanical properties, thermal stability, biological resistance, and its hygroscopic characteristics, can be modified by impregnating the wood with nano-sized particles (Xanthos 2005, Lotfizadeh et al. 2012, Akhtari and Arefkhani 2013, Akhtari et al. 2012b). In a study of wood impregnated with $\mathrm{TiO}_{2}$ and nanoclays, the specimens treated with nanoparticles had improved fire resistance. The water vapor results indicated that all treated specimens had greater resistance to the uptake of water vapor flow than the untreated specimens (Fufa et al. 2012, Fufa et al. 2013b). In another study in which the specimens were impregnated with nano-silver, it was found that modulus of rupture decreased by only $4.8 \%$ in beech but increased by $1.7 \%$ in poplar. There was a decrease in the compression strength parallel to the grain for both types of wood (Taghiyari et al. 2012).

Taghiyari 2012, assessed the gas and liquid permeability of woods that were impregnated with nano-silver. The results showed that permeability increased by more than $50 \%$ in poplar and hornbeam heartwood, which have simple perforation plates. However, permeability decreased by $3.7 \%$ in Beech. In another study of the mechanical properties of paulownia wood impregnated by silver, cooper, and zinc oxide nanoparticles, the modulus of rupture (MOR), modulus of elasticity (MOE), and compression strength parallel to the grain increased significantly in all cases. The greatest increase was observed in the specimens impregnated with nano-copper (Akhtari et al. 2012a). Studies conducted on the impregnation of wood with nanoparticles have included the use of nanoclay, nano-silver, and other metallic particles. This study was the first to use nanoboron nitride, which has high resistance to fire, to improve the mechanical properties and thermal stability of wood.

The aim of the study was to investigate the effect of NBN on the mechanical properties such as flexure strength/modulus, compression strength and thermal stability of heat-treated and untreated wood. Many cracks and cell collapse may take place on the woods during heat-treatment, and the impregnation can applies hardly. Therefore, the distribution of the nanoparticles throughout and inside the pores of the heat-treated wood specimens was also investigated via scanning electron microscopy (SEM/EDAX), and the differences were compared with un-treated woods.

\section{MATERIALS AND METHODS}

\section{Materials}

Heat-treated (i.e., $215^{\circ} \mathrm{C}$ for $12 \mathrm{~h}$ ) and un-treated Scots pine (Pinus sylvestrist L.), Ash (Fraxinus exelsior), and Iroco (Chlorophora excelsa) woods were obtained from Nova ThermoWood Inc. (Bolu, Turkey) as timber that measured $20 \times 20 \times 100 \mathrm{~cm}$. The wood cut into blocks with the dimensions of $2 \times 2 \times 30 \mathrm{~cm}$. All of the samples were weighed and conditioned to $12 \% \mathrm{MC}$ for one month prior to impregnation. The samples were divided randomly into four groups, i.e., control, control-impregnated, heat-treated and heat-treated and impregnated specimens. The groups and their abbreviations are given in table 1.

Table 1. Test groups and abbreviations used for the samples.

\begin{tabular}{|c|c|c|c|}
\hline Wood Types & Abbreviation & Wood Types & Abbreviation \\
\hline Untreated Scots Pine & SPC & Heat-treated Ash & ATW \\
\hline $\begin{array}{l}\text { Untreated Scots Pine- } \\
\text { Impregnation }\end{array}$ & SPCI & $\begin{array}{l}\text { Heat-treated Ash- } \\
\text { Impregnation }\end{array}$ & ATWI \\
\hline Heat-treated Scots Pine & SPTW & Untreated Iroco & IC \\
\hline $\begin{array}{l}\text { Heat-treated Scots Pine- } \\
\text { Impregnation }\end{array}$ & SPTWI & $\begin{array}{l}\text { Untreated Iroco- } \\
\text { Impregnation }\end{array}$ & ICI \\
\hline Untreated Ash & $\mathrm{AC}$ & Heat-treated Iroco & ITW \\
\hline Untreated Ash-Impregnation & $\mathrm{ACI}$ & $\begin{array}{l}\text { Heat-treated Iroco- } \\
\text { Impregnation }\end{array}$ & ITWI \\
\hline
\end{tabular}


Hexagonal boron nitride (hNBN) was obtained from BORTEK - BOR Technologies, Inc. This chemical compound has the formula BN, so it consists of boron and nitrogen elements. The hexagonal formation is stable and softest among the BN polymorphs. Boron nitrides cannot be naturally obtained, so they are chemically synthesized by reacting boron trioxide or boric acid with ammonia or urea (Rudolph 2000, Robert and Chaitanya 1990). The h-BN has a specific gravity of $2.27 \mathrm{~g} / \mathrm{cm}^{3}$ and a melting range of $2700-3000{ }^{\circ} \mathrm{C}$. It consists of thin plates that have an average diameter of about 200 $\mathrm{nm}$ and a thickness of $80 \mathrm{~nm}$ (Ayrilmis et al. 2014). Figure 1 shows NBN on the surface of the wood.

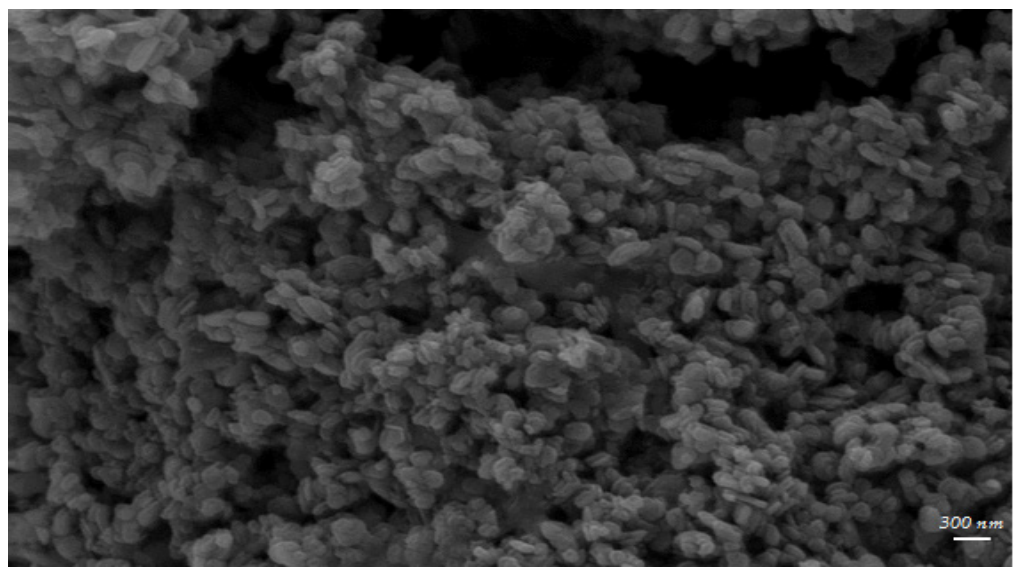

Figure 1. The dispersion of NBN on the surface of the wood.

\section{Impregnation Process}

The samples were impregnated with $3 \%$ dispersion of $\mathrm{hBN}$ in water according to the ASTM D-1413 (1976) standard method. Wood samples were treated at $600 \mathrm{~mm}-\mathrm{Hg}$ vacuum for $30 \mathrm{~min}$ and at a pressure of $0.6 \mathrm{MPa}$ for $60 \mathrm{~min}$. The impregnation process was conducted according to Taghiyari et al. (2013). The size range of the $\mathrm{hBN}$ particles was $20-80 \mathrm{~nm}$. After impregnation, the samples were weighed before and after impregnation to measure the retention ratio of the $\mathrm{hBN}$. The impregnated samples were conditioned at $90 \% \mathrm{RH}$ in a climatic cabinet until $11-12 \%$ during a month.

\section{Methods}

Retention ratio; after impregnation, the retention ratio (\%) for each sample was calculated according to Eq. 1:

$$
R\left(\frac{K g}{m^{3}}\right)=\frac{G \times C}{V} \times 100
$$

Where, $\mathrm{G}$ is the weight of the treatment solution absorbed by the block (initial weight of the block subtracted from the initial weight plus the absorbed treatment solution); $\mathrm{C}$ is the weight of the chemical solution in $100 \mathrm{~g}$ of the treatment solution; and $\mathrm{V}$ is the volume of the block in cubic centimeters.

Density; samples (20x20x30 mm) were prepared, and tests for density $\left(\mathrm{g} / \mathrm{cm}^{3}\right)$ at $0 \%$ and $12 \% \mathrm{MC}$ were conducted according to ASTM D2555 - 06 (2011). 
Mechanical properties; an Utest mechanical tester was used to determine the mechanical performance of the samples. All of the tests were conducted in accordance with ASTM D014394 (2007). For flexure strength/modulus, the size of the specimens was $20 \times 20 \times 300 \mathrm{~mm}$, and the size of the specimens for compression strength parallel to the grain was $20 \times 20 \times 30 \mathrm{~mm}$. The samples were conditioned to a temperature of $20 \pm 3{ }^{\circ} \mathrm{C}$ and $65 \%$ relative humidity prior to the test. The results were determined as $\mathrm{MPa}$. Strength values were corrected based on $12 \%$ moisture content according to ISO 3130 (1975) using the following strength conversion equation:

$$
\delta_{12}=\delta_{m} x\left[1+\alpha\left(M_{2}-12\right)\right]
$$

where $\delta_{12}$ is the strength at a $12 \%$ moisture content $\left(\mathrm{N} / \mathrm{mm}^{2}\right), \delta_{\mathrm{m}}$ is the strength at a moisture content different from $12 \%\left(\mathrm{~N} / \mathrm{mm}^{2}\right), \alpha$ is a constant value showing the relationship between the strength and moisture content ( $\alpha=0.05$; for $\sigma \mathrm{c} / /$ ), and $\mathrm{M}_{2}$ is the moisture content during the test (\%).

Color Changes; color measurements of all of the specimens were taken on the surface of the wood specimens. The sensor head was $6 \mathrm{~mm}$ in diameter. Measurements were made using a D65 illuminant and a 10-degree standard observer.

$$
\Delta E a b^{*}=\sqrt{\left(\Delta L^{*}\right)^{2}+\left(\Delta a^{*}\right)^{2}+\left(\Delta b^{*}\right)^{2}}
$$

From the $\mathrm{L}^{*}, \mathrm{a}^{*}$, and $\mathrm{b}^{*}$ values, the differences in the lightness $\left(\Delta \mathrm{L}^{*}\right)$ and chroma coordinates $\left(\Delta \mathrm{a}^{*}\right.$ and $\left.\Delta \mathrm{b}^{*}\right)$, as well as the total color difference $\left(\Delta \mathrm{Eab}^{*}\right)$ between the colors of the samples, were calculated according to DIN5033.

Thermogravimetric analysis (TGA/DTA/DTG); the thermal stability of the samples was investigated using thermogravimetric analysis (TGA /DTG/DTA) (Perkin Elmer, TA Instruments, USA). The samples were heated from $25^{\circ} \mathrm{C}$ to $600{ }^{\circ} \mathrm{C}$ with a heating rate of $10^{\circ} \mathrm{C} / \mathrm{min}$ and a nitrogen flow of $100 \mathrm{~mL} / \mathrm{min}$. The samples that were used weighed about $1 \mathrm{~g}$.

Scanning Electron Microscopy (SEM/EDAX); the morphology of the surfaces and radial direction after fracture of the samples under nitrogen were observed with an environmental scanning electron microscope (ESEM) (Phillips Electroscan 2020) with an accelerating voltage of $5 \mathrm{kV}$. The surfaces and radial surface of all samples were sputter-coated with gold using a Denton sputter coater for enhanced conductivity.

Statistical Analysis; Statistical analysis was conducted using SPSS 16 software. One-way analysis of variance (ANOVA) was performed to identify significant differences at the $99 \%$ confidence level. The Duncan test was used to determine the difference between groups. It was found that there were important differences between groups after impregnation.

\section{RESULTS AND DISCUSSION}

\section{Retention and Density of the Samples}

After impregnation with $\mathrm{hBN}$, the retention and density of the samples were determined. According to the statistical results obtained, the differences in the samples after impregnation were found to be significant by using the one-way ANOVA/Duncan test. Figures 2 and 3 show the retention and the density of the samples. 


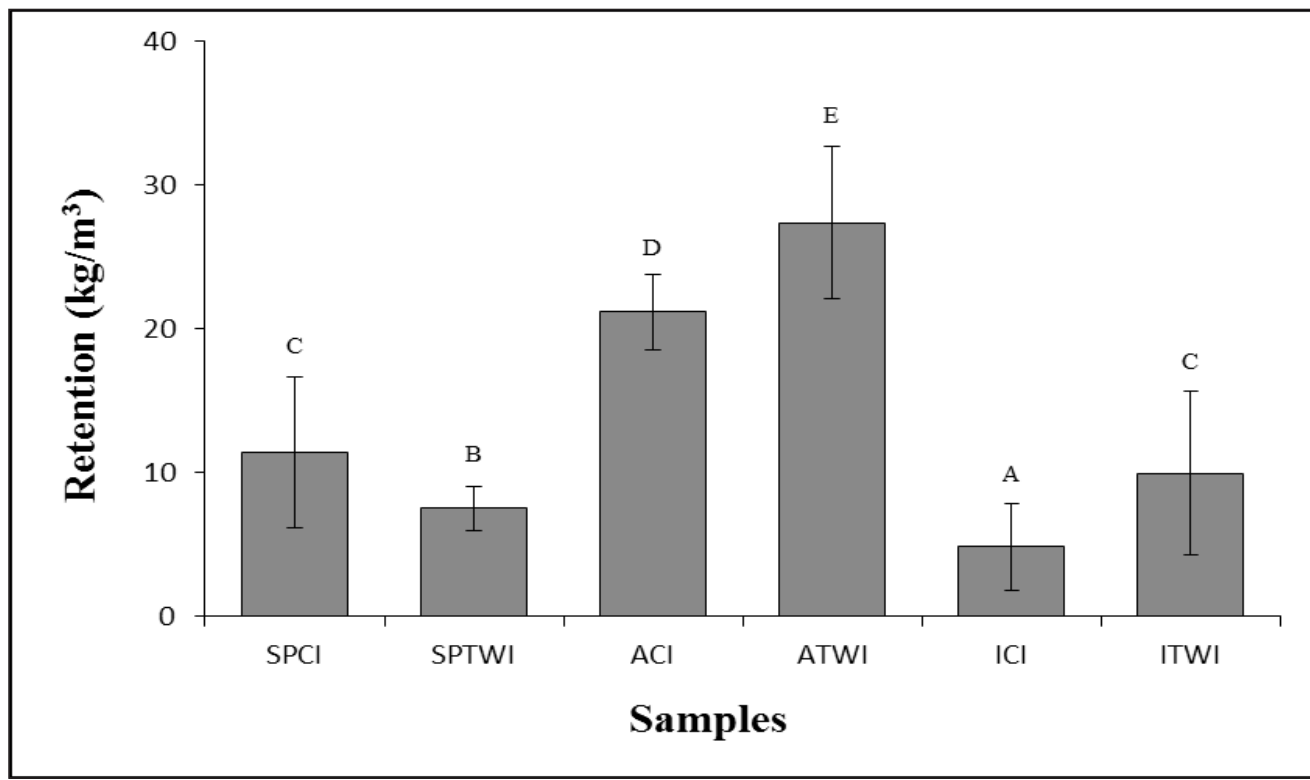

Figure 2. Retention values of all of the samples.

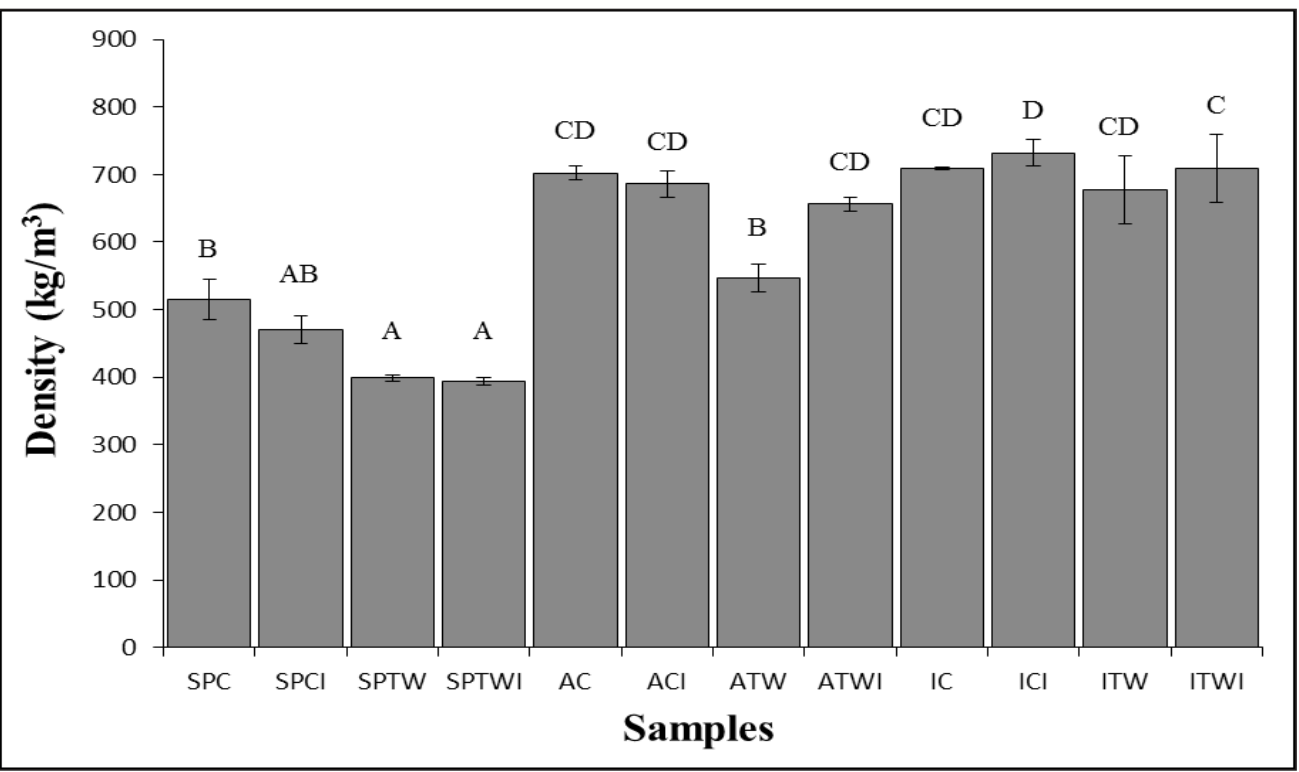

Figure 3. Densities of the samples.

The maximum value among the samples was $27.4 \mathrm{~kg} / \mathrm{m}^{3}$, which was determined for ATWI. ICI had the minimum value of retention. After impregnation, the retention value increased for both ash and Iroco wood, but it decreased for Scots pine wood. The results indicated that the impregnation process had different effects on all of the samples, with the density values generally increasing. The maximum value of density was found in ICI with $732 \mathrm{~kg} / \mathrm{m}^{3}$. Interestingly, the density of impregnated control Scots pine wood decreased with impregnation. Similar to the change in density, the mechanical 
properties also changed to all samples. Figures 4 and 5 show the changes in the flexure strength/ flexure modulus and compression strength. After impregnation, flexure strength increased for all of the samples. The maximum increase in flexure strength of $24.5 \%$ was determined for the control ash wood after impregnation. The minimum increase in flexure strength of $13 \%$ was observed for the heat-treated Scots pine wood. The impregnation process had a negative effect on the modulus of elasticity for all samples except for the Scots pine control and the heat-treated Iroco wood. The greatest improvement in the modulus of elasticity was found in the Scots pine control (13.8\%) and the greatest decrease in the modulus of elasticity was found in the heat-treated Scots pine (24.7\%). After impregnation with $\mathrm{hBN}$, the compression strength for all of the Scots pine and Iroco wood samples decreased, but it was found to increase for all ash wood samples. Taghiyari et al. (2012), found that MOR decreased by $4.8 \%$ in beech and increased by $1.7 \%$ in poplar when the specimens were impregnated with nanosilver. The nano-silver impregnation decreased the amount of losses in MOR, MOE, and compression strength parallel to the grain. Consequently, the mechanical properties were improved by preventing the formation of microscopic fissures and surface checks. Akhtari et al. (2012a), worked on wood impregnated with silver, copper and zinc oxide nanoparticles. The results showed that the modulus of rupture (MOR), modulus of elasticity (MOE), and compression strength parallel to the grain increased significantly in all cases. The greatest increase was observed in nano copper-impregnated specimens.

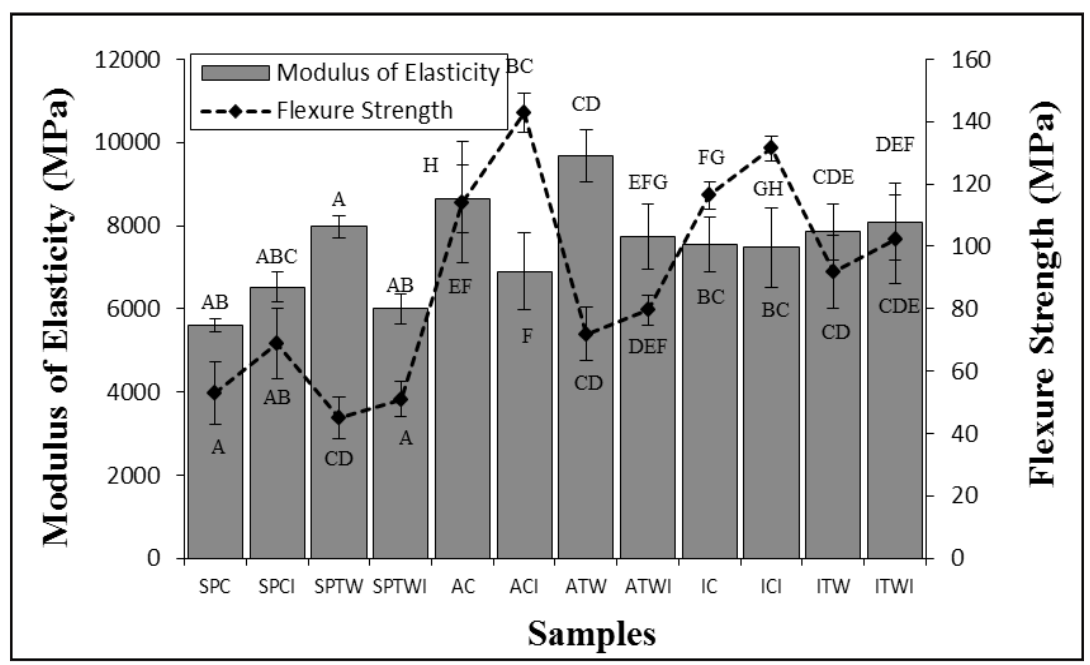

Figure 4. Flexure strength and modulus of elasticity in flexure of all of the samples.

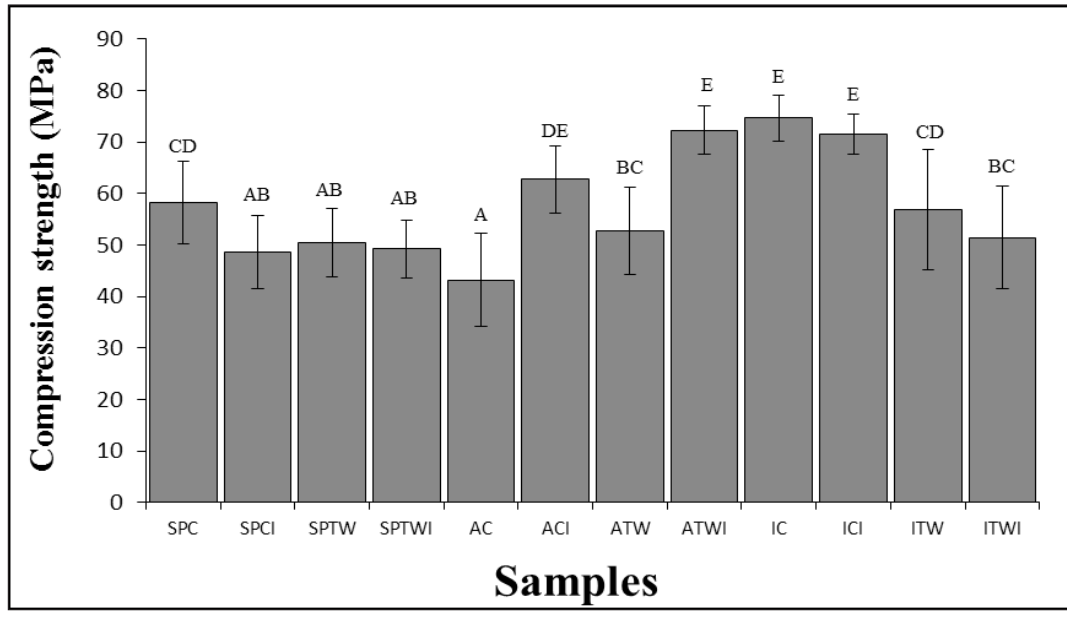

Figure 5. Changes in the compression strength of the all of the samples. 
After the impregnation process, changes in the colors of all of the samples also were investigated. The results were statistically analyzed using one-way ANOVA, and then the Duncan test was done. Figure 6 shows the changes in the color of the all samples. The obtained data showed that the color values of all the samples changed significantly. It was also determined that $\mathrm{L}^{*}$ values decreased with $\mathrm{BN}$; the minimum changes in $\mathrm{L}^{*}$ was found in the impregnated control samples. The $\mathrm{a}^{*}$ and $\mathrm{b}^{*}$ values changed for varying levels with BN. The minimum total color change was found to be $2.5 \%$ for ACI, and the maximum total color change was determined as 32.5\% for ATWI. Afrouzi et al. (2013), assessed wood that was impregnated with nano-zinc oxide. The results showed that the amount of color change of samples treated with nano zinc oxide was less than it was in the untreated samples. Thus, the amounts of color change were found to decrease as the concentration of the impregnating material increased. As a result, it can be said that $\Delta \mathrm{L}^{*}$ decreased with impregnation and that the changes in $\mathrm{a}^{*}$ and $\mathrm{b}^{*}$ varied among the samples. In another study, the results showed that there were no obvious color changes between the heat-treated specimens without impregnation and heat-treated samples impregnated with the nano-silver. But, the color change was more obvious at the cross-ends of the specimens. A change of color to dark brown also was obvious; this darkness occurred to a greater extent in the nano-silverimpregnated specimens, and, in some parts, it tended to be grayish black (Taghiyari et al. 2013). Figure 7 shows the total color changes in the samples.

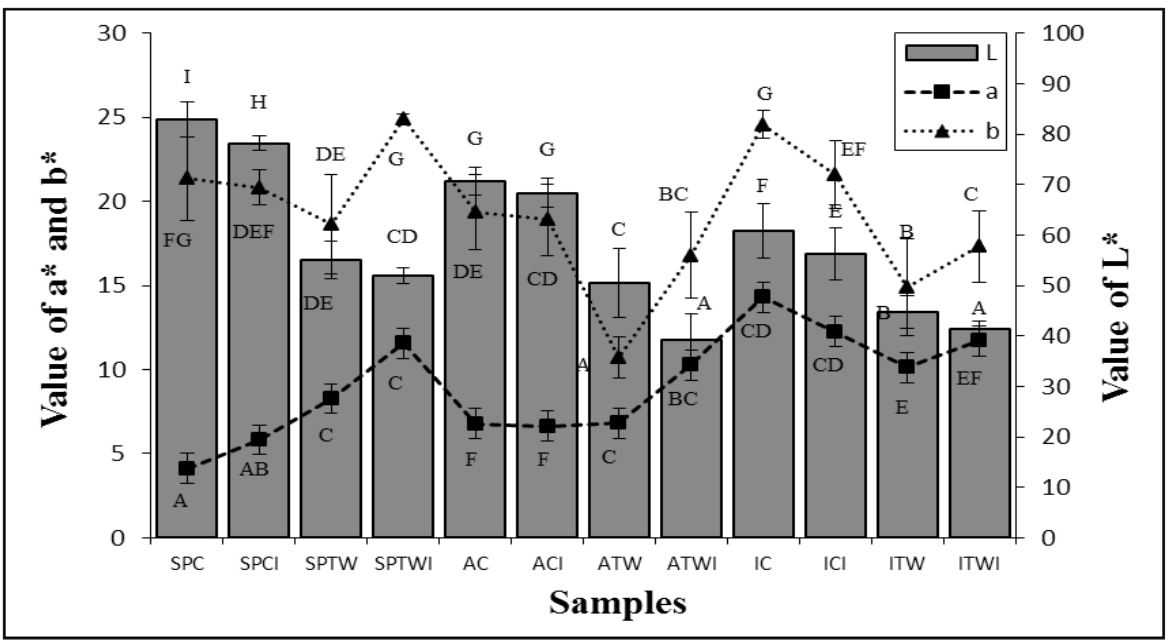

Figure 6. $\mathrm{L}^{*}, \mathrm{a}^{*}$, and $\mathrm{b}^{*}$ values of all the composites after impregnation.

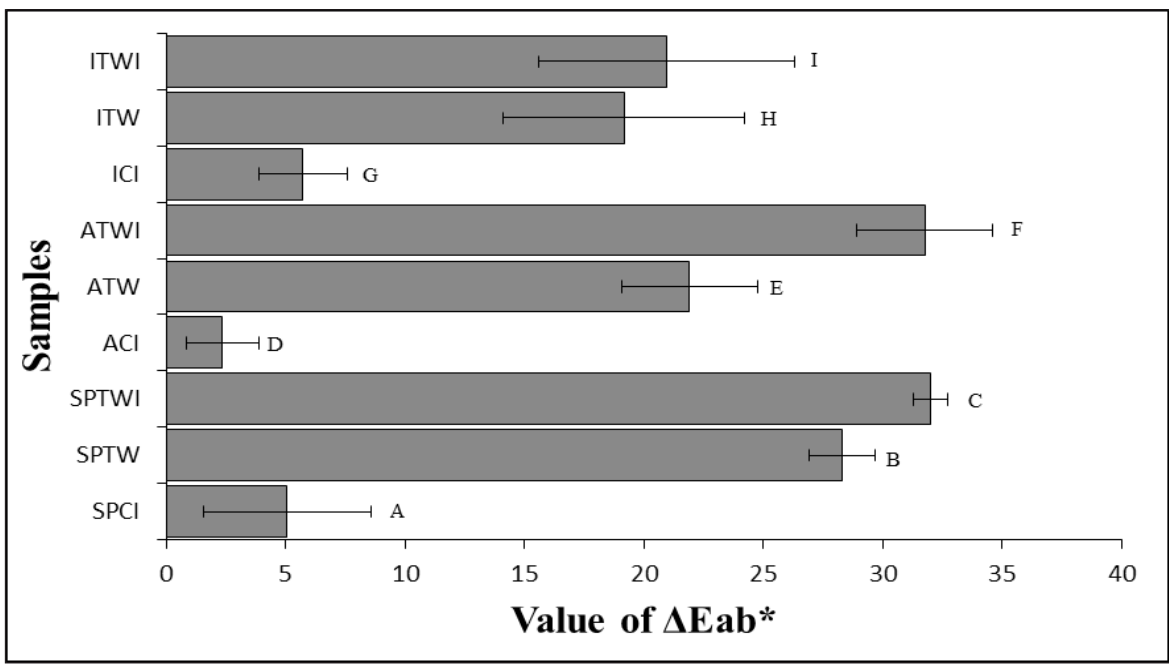

Figure 7. Total color changes $\left(\Delta \mathrm{Eab}^{*}\right)$ in the samples after impregnation. 
Figure 7 shows that the impregnation had an important effect on the value of $\Delta E a b^{*}$. After impregnation, total color changes for all the samples were found to decrease for the control samples. In the heat-treated wood, the value of $\Delta \mathrm{Eab}$ * increased for the samples that were impregnated with $\mathrm{hBN}$. In a similar study, samples impregnated with nano zinc oxide did not show any color changes for three concentrations, i.e.; $0.5 ; 1.0$ and $1.5 \%$ (Afrouzi et al.2013). Consequently, with the impregnation of wood, $\Delta \mathrm{Eab}^{*}, \mathrm{~L}^{*}, \mathrm{a}^{*}$, and $\mathrm{b}^{*}$ values were found to change by different percentages. The thermal stability of wood was investigated after impregnation.

Figures 8 show the TGA/DTG and DTA curves of the results obtained, respectively. According to the TGA curves in Figure 8, three regions were found for the starting and ending points of the curves, composing the thermal breakdown of the organic matter and other volatile compounds in the samples. The first region (100 to $200{ }^{\circ} \mathrm{C}$ ) shows the evaporation of extractives and water loss in the wood. The second region $\left(200\right.$ to $350{ }^{\circ} \mathrm{C}$ ) includes the decomposition (Td) of the major chemical constituents of the wood. Third region is between 350 and $500^{\circ} \mathrm{C}$ (Markova 1998).

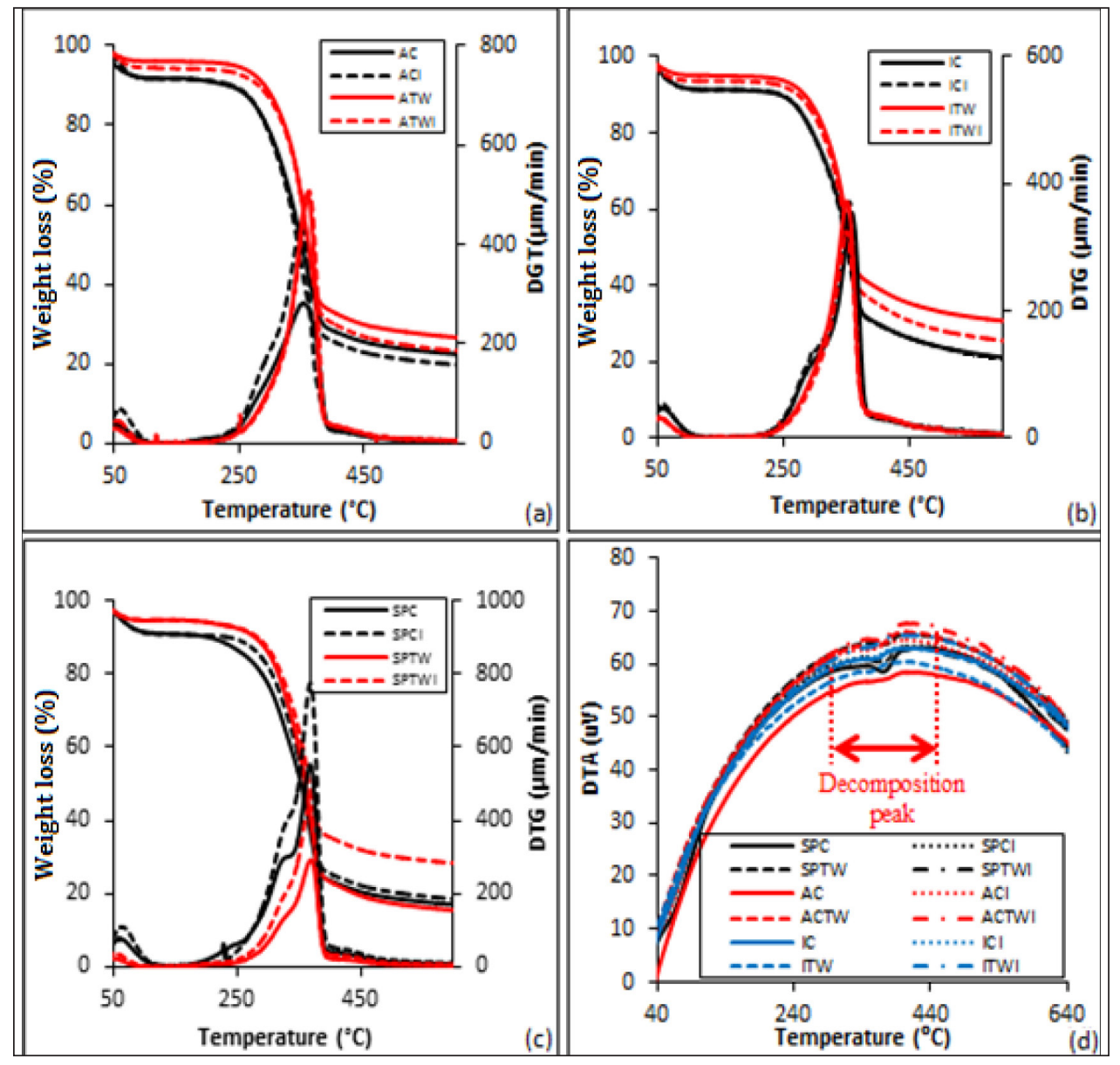

Figure 8. TGA/DTG/DTA analysis of all of the samples after impregnation: (a), Weight loss curves for Ash (Fraxinus excelsior); (b), Weight loss curves for Iroco (Chlorophora excels); (c), Weight loss curves for Scots Pine (Pinus sylvestrist) and (d), DTA curves for all samples.

In analyzing the TGA/DTA curves, it was apparent that the thermal stability of the impregnated samples was better than that of the samples that had not been impregnated. DTG curves displayed in Figure 8 allow a comparison of the thermal stability between the heat-treated and untreated wood species with and without impregnation with $\mathrm{hBN}$. The degradation profiles show two peaks, i.e., the first peak between 40 and $80^{\circ} \mathrm{C}$ and the degradation peak between 250 and $450{ }^{\circ} \mathrm{C}$. Table 2 summarized 
the results obtained from the TGA/DTGA and DTA curves. For all of the samples, Table 2 shows $\mathrm{T}_{10 \%}$, $\mathrm{T}_{50 \%}, \mathrm{DTG}_{\max }$, mass loss, and the DTA peaks, which were calculated from the TGA/DTG and DTA curves.

Table 2. TGA and DTA summary of the heat-treated and un-treated samples after impregnation.

\begin{tabular}{lllccc}
\hline Samples & $\begin{array}{l}\mathbf{T}_{\mathbf{1 0} \%} \\
\left({ }^{\mathbf{C}} \mathbf{C}\right)\end{array}$ & $\begin{array}{c}\mathbf{T}_{\mathbf{5 0} \%} \\
\left({ }^{\mathbf{(}} \mathbf{C}\right)\end{array}$ & $\begin{array}{c}\mathbf{D T G}_{\mathbf{m a x}} \\
\left({ }^{\mathbf{0}} \mathbf{C}\right)\end{array}$ & $\begin{array}{c}\text { Mass Loss } \\
(\mathbf{\%})\end{array}$ & $\begin{array}{c}\text { DTA Peak } \\
(\mathbf{u V})\end{array}$ \\
\hline SPC & 205 & 353 & 367.4 & 84 & 370.2 \\
SPCI & 217 & 358 & 367.8 & 83 & 371.3 \\
SPTW & 278 & 360 & 367.2 & 80 & 371.7 \\
SPTWI & 283 & 366 & 366.8 & 75 & 370.5 \\
$\boldsymbol{A C}$ & $\mathbf{2 3 2}$ & $\mathbf{3 4 9}$ & $\mathbf{3 5 3 . 5}$ & $\mathbf{7 9}$ & $\mathbf{3 6 7 . 1}$ \\
$\boldsymbol{A C I}$ & $\mathbf{2 3 8}$ & $\mathbf{3 5 0}$ & $\mathbf{3 4 9 . 7}$ & $\mathbf{8 0}$ & $\mathbf{3 5 0 . 4}$ \\
$\boldsymbol{A T \boldsymbol { W }}$ & $\mathbf{2 8 8}$ & $\mathbf{3 6 0}$ & $\mathbf{3 5 9 . 5}$ & $\mathbf{7 5}$ & $\mathbf{3 6 0 . 3}$ \\
$\boldsymbol{A T W I}$ & $\mathbf{2 8 5}$ & $\mathbf{3 6 2}$ & 361.3 & 77 & $\mathbf{3 6 5 . 4}$ \\
IC & 241 & 351 & 356.4 & 80 & 358.9 \\
ICI & 245 & 353 & 355.2 & 81 & 358.3 \\
ITW & 276 & 354 & 350.4 & 73 & 351.1 \\
ITWI & 279 & 357 & 351.8 & 75 & 353.2 \\
\hline
\end{tabular}

The degradation temperature of the samples generally increased with impregnation except for ATWI at $\mathrm{T}_{10 \%}$. The maximum and minimum increases of $\mathrm{T}_{10 \%}$ were found for SPCI and ITWI, respectively. The increase in $\mathrm{T}_{10 \%}$ likely occurred due to NBN's retarding degradation. $\mathrm{T}_{10 \%}$ values were delayed with the impregnation of $\mathrm{hBN}$ because the surfaces of all of the samples were covered with NBN. For $\mathrm{T}_{50 \%}$, the impregnation with NBN delayed degradation until higher temperatures were attained and the degradation temperature for all heat-treated and impregnated samples increased with NBN as compare with un-treated and un-impregnated (control) samples. The degradation temperature at $\mathrm{T}_{10 \%}$ for ATWI decreased after impregnation process. These phenomena indicate that the $\mathrm{hBN}$ was not homogenously distributed throughout some parts of the samples. The changes in the $\mathrm{T}_{50 \%}$ and mass loss can be explained with in this status. It can be said conclusively that the impregnation with NBN will be more positive effect on thermal stability, if the dispersion of the particles can be provided homogenously. In a study on fire resistance of wood impregnated with fire retardants, i.e., nano- $\mathrm{TiO}_{2}$ and nanoclay, nanoparticles containing treatments were found to be less effective for improving the fire performance of fire retardants without nanoparticles (Fufa et al. 2013a).

Many fire retardants improve the thermal stability of wood, but some of them have low efficiency, and their leaching can lead to significant environmental and health risks. But the use of hBN alone or with combination of other environmentally-friendly chemicals can improve the thermal stability and lower the flammability of wood. Therefore, low-cost, environmentally-friendly fire retardants can be developed by combining other constituents with nano-hBN. One of major challenges of nanoimpregnation process is having the nanoparticles permeate deeply into the wood. To determine the status of the permeation, SEM analysis was conducted for both untreated and heat-treated wood. Figures 10 and 11 show the SEM photographs that were obtained untreated and heat-treated wood, respectively. Figures 10 (a) and (b) show thick white layers on the cross section and on the side surface of the wood after impregnation. Figures 10 (c), (d), and (e) show the fractured surface with white deposits, which also were found inside the surface of the vessel and cells. Figures 10 (f) and (g) show that the hBN had aggregated the white deposits on or around the pits. The white deposits can clearly be seen inside the cell lumen and on the pits. Similar SEM photographs were obtained for all the types of wood. Figures 11 shows the SEM photographs of the heat-treated samples with $\mathrm{hBN}$, and it are apparent that the same results were obtained; however, the density of the white deposits was found to be much less. This phenomenon occurred due to the forced permeability because of cell collapse in the wood after heat treatment. Matsunaga et al. 2009 evaluated the micro dispersion of different nano/macro particles in wood. According to SEM results, they were found to be the deposition of nano/macro particles in wood, including their sizes and shapes. The particles were determined to form aggregates around the pits, but they found not to able to penetrate into the pits. The nanoparticles also 
aggregated in the chamber of the bordered pits that connect the fibers, but, in contrast to the ray pits, the nanoparticles appeared to be able to pass through the bordered pits. In another study conducted to determine the effect of heat treatment on the permeability of wood, the results showed that there was a sharp decrease in permeability at $75^{\circ} \mathrm{C}$ due to irreversible hydrogen bonding in the course of the movement of water within the vessels' perforations and the pore system of the cell walls. It was found that the gradual increase in permeability at higher temperatures, though, might be due to higher internal stresses that are released as micro-cracks develop (Taghiyari 2013).

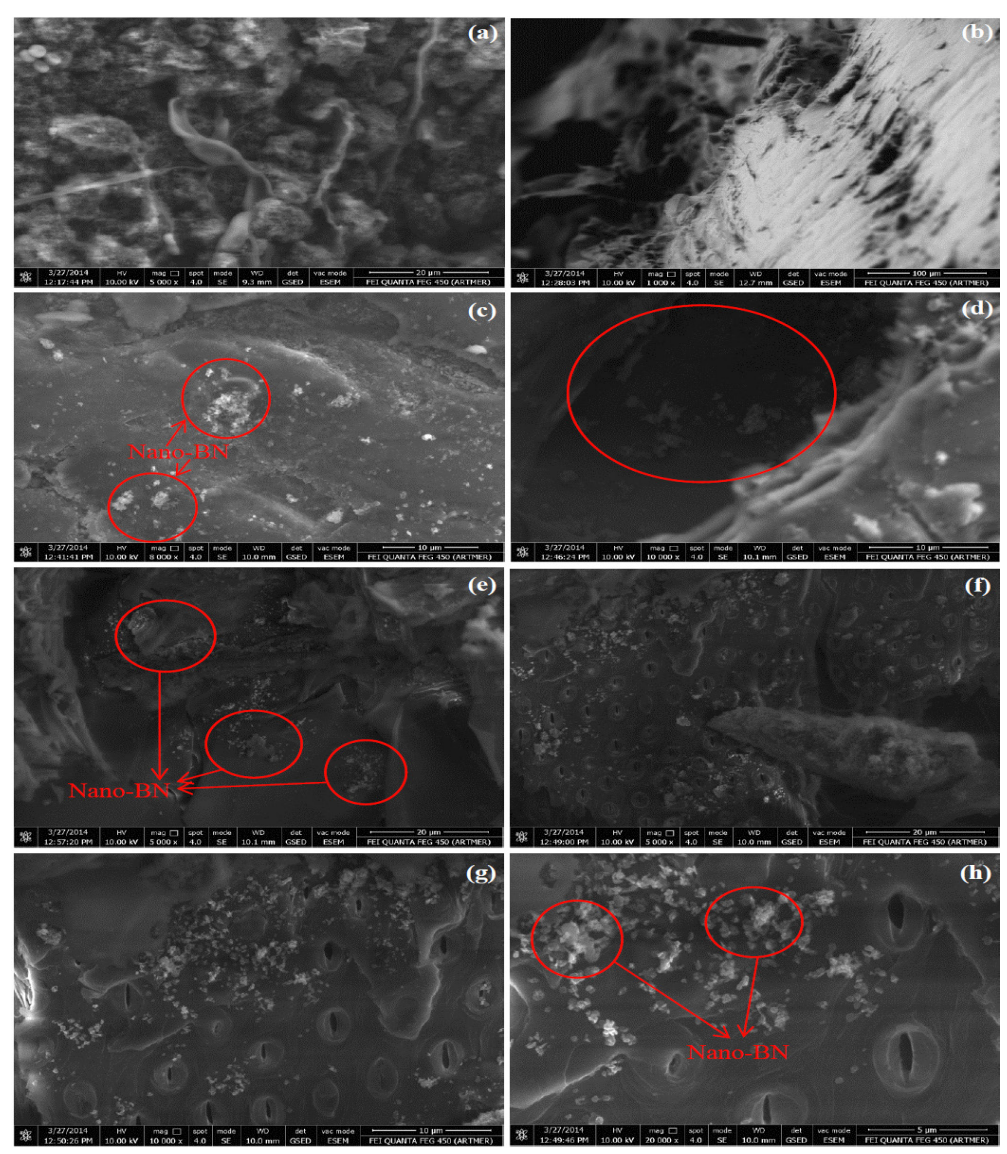

Figure 10. SEM photographs of untreated wood impregnated with hBN. (a, b, c and d: NBN on the fracture surface of the samples and e, $\mathrm{f}, \mathrm{g}$ and $\mathrm{h}$ : NBN on, around and inside pits. 

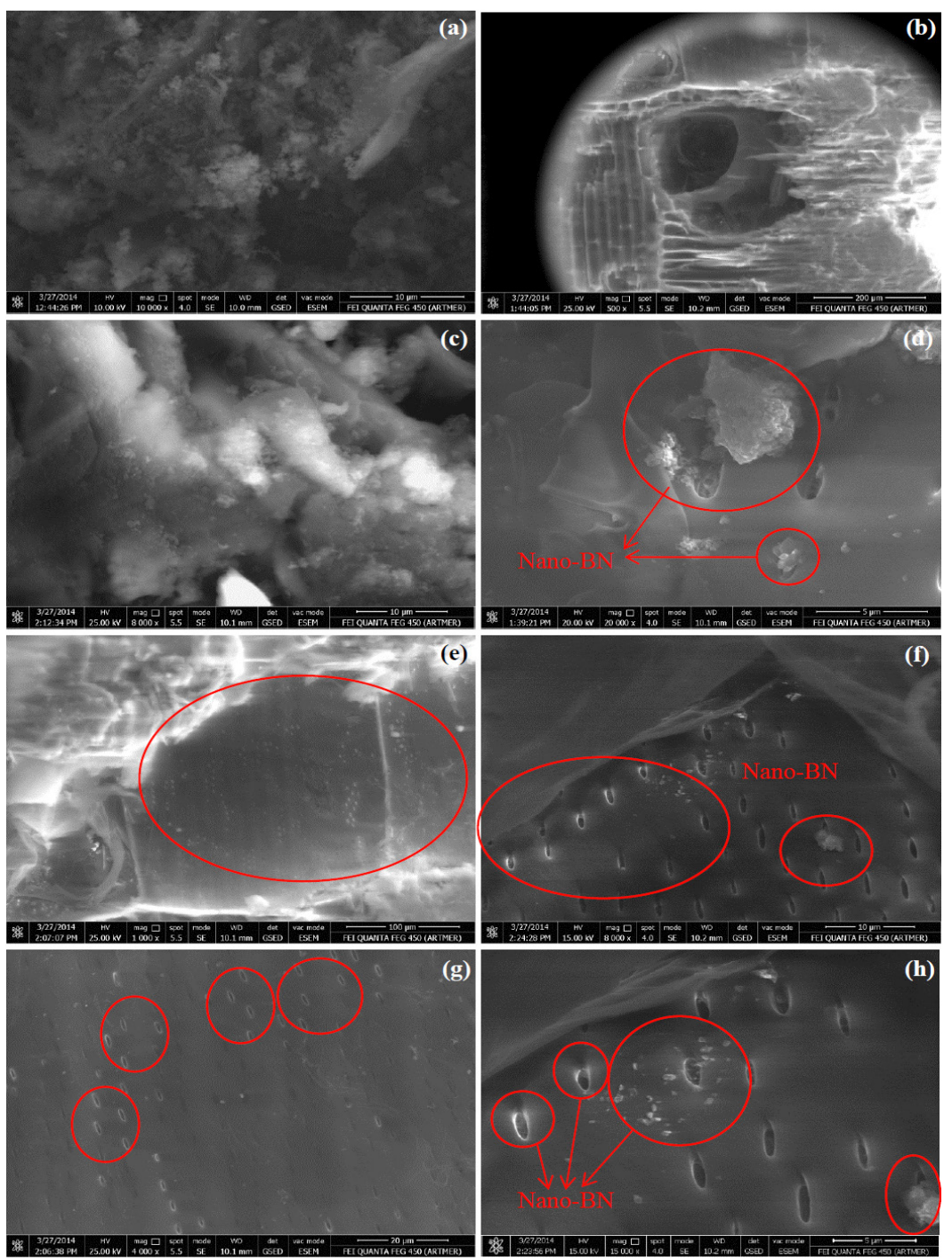

Figure 11. SEM photographs of heat-treated wood impregnated with hBN. (a, b, c and d: NBN on the fracture surface of the samples and e, f, $g$ and $h$ : NBN on, around and inside pits.

In another study of the impregnation of Paulownia wood with nanoparticles, numerous deposits are present on the tertiary cell wall layer adjacent to the lumens of the tracheids and rays. These deposits contrasted strongly with the walls of the wood's cells. These deposits were found to consist of the inorganic elements (i.e., copper, zinc, and silver) found in the preservative with nano-particles. The deposits consisted of small particles, some of which appeared to be crystalline. The SEM results showed that the pit structures of the un-decayed samples had almost symmetrically round apertures, and the borders were intact and unblemished (Akhtari et al. 2012a). Considering the SEM photographs, it can be said that the white deposits on the cell elements and on, around and inside the pits were the $\mathrm{hBN}$ particles. To prove this, EDX analysis was done and the graph of the results obtained is presented in figure 12. 


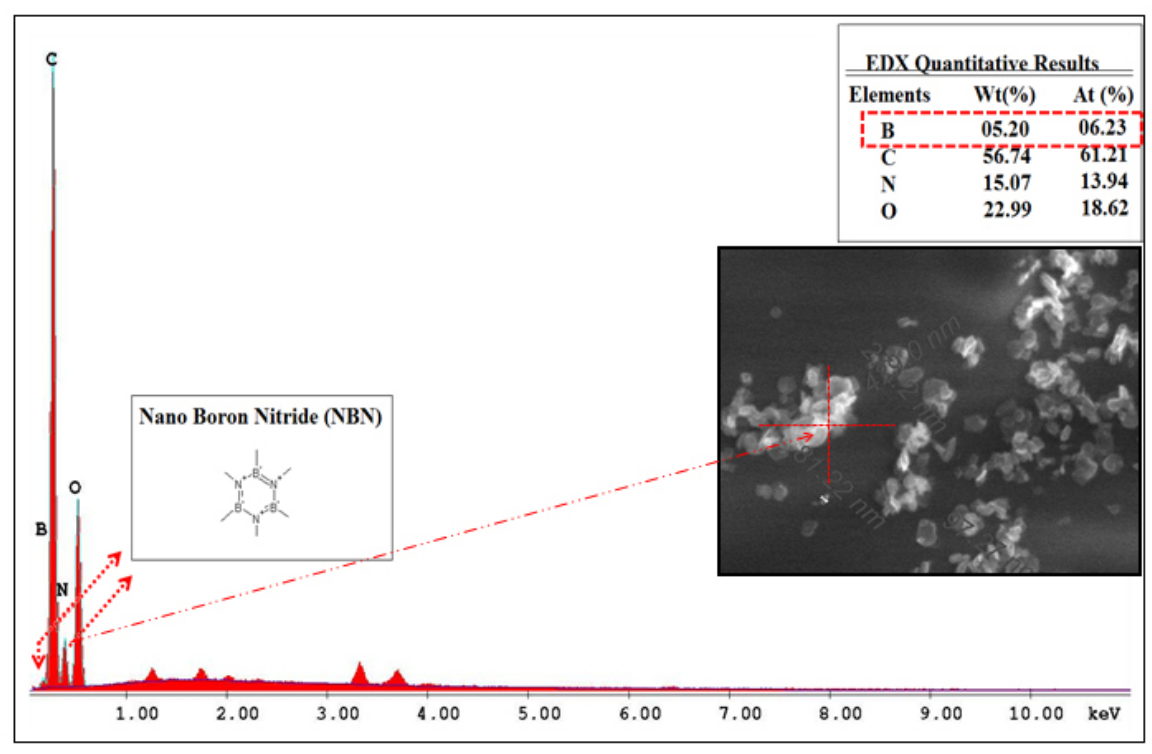

Figure 12. EDAX analysis of the white deposits inside the wood after impregnation.

The SEM-EDAX results showed the white formations on cell wall and around the pits. The white formations on the cells of the wood, which has obtained an elemental composition of $56.4 \% \mathrm{C} ; 22.9 \%$ $\mathrm{O} ; 5.2 \% \mathrm{~B}$; and $15.4 \% \mathrm{~N}$, can be said as the deposits consisted of hBNs. Elemental analysis with SEM showed that the white formations contained boron and nitrogen, as indicated in Figure 12. Same EDAX results were found to all un-treated and heat-treated woods. According to the results, it can be said that white formations on the on, around and inside the pits and vessels is the NBN particles.

In a study conducted with different nanoparticles, it was found that these formations were concentrated on or around the pits and they were observed inside the fibers or vessels The strong contrast between the deposits and the cell wall, which has an elemental composition of $53 \% \mathrm{C} ; 40 \%$ $\mathrm{O} ; 6.5 \% \mathrm{H}$ and $0.5 \% \mathrm{~N}$, strongly suggested that the deposits consisted of inorganic elements. Mapping also revealed iron in the same regions of the wood microstructure where copper was found (Matsunaga et al. 2009). Landry et al. 2013, used Metal Oxide Sol-Gels $\left(\mathrm{ZrO}_{2}, \mathrm{AlO}(\mathrm{OH})\right.$, and $\left.\mathrm{SiO}_{2}\right)$ to improve the mechanical performance of wood. The results showed that white aggregates can be observed in the wood cells. These aggregates represent $\mathrm{SiO}_{2}$ gel particles as identified by the elemental analysis (SEM-EDAX).

\section{CONCLUSIONS}

A solution of $3 \% \mathrm{hBN}$ was impregnated into heat-treated and untreated woods under vacuum and pressure. $\mathrm{hBN}$ nanoparticles were determined within the lumen of the vessels using SEM spectroscopy. When taking account the result, it can be said that $\mathrm{hBN}$ nanoparticles were determined on or around and inside the pits. Elemental boron and nitrogen in the cell walls and vessels in both heat-treated and untreated wood impregnated with hBN were detected with EDAX. A mechanism for the delivery of hBN into the cell walls could be used more efficiently in protecting wood and improving its thermal stability with nanoparticles by changing the sizes of the particles. After impregnation, the mechanical properties of wood were found to increase by approximately $25 \%$. This increase was a favorable outcome, given that conventional protection chemicals decrease the mechanical properties of the impregnated wood. The impregnation of wood with $\mathrm{hBN}$ had a positive effect on the wood's mechanical properties and thermal stability. Thus, new studies should be conducted on wood impregnated with hBN and also to explore approaches for the deep penetration of the nanoparticles into the structure of the wood. If woods are going to be heart treated, the impregnation of the nanoparticles should be conducted prior to 
the heat treatment to reduce the extent to which wood's cells deteriorate with heat treatment.

\section{REFERENCES}

Afrouzi, Y.; Omidvar, A.; Marzbani, P. 2013. Effect of Artificial Weathering on the Wood Impregnated with Nano-Zinc Oxide. World Applied Sciences Journal 22(9): 1200-1203.

Akhtari, M.; Arefkhani, M. 2013. Study of Microscopy Properties of Wood Impregnated with Nanoparticles during Exposed to White-Rot Fungus. Agriculture Science Developments 2(11): 116119.

Akhtari, M.; Ghorbani-Kokandeh, M.; Taghiyari, H.R. 2012a. Mechanical properties of Paulownia fortunei wood Impregnated with silver, copper and zinc oxide Nanoparticles. Journal of Tropical Forest Science 24(4): 507-511.

Akhtari, M.; Kokandeh, M.G.; Taghiyari, H.R. 2012b. Potential Usage Of Nanotechnology In Wood Drying: Treating Poplar Boards with Nano-metals Affects The Drying Behavior. Digest Journal of Nanomaterials and Bio-structures 7(4): 1627-1637.

ASTM International. 2007. Standard Test Methods for Small Clear Specimens of Timber., ASTM D0143-94. West Conshohocken, PA:19428-2959 USA.

ASTM International. 1976. Standard Method of Testing Wood Preservatives By Laboratory Soil block Cultures. ASTM-D 1413. West Conshohocken, PA: 19428-2959 USA.

ASTM International. 2011. Standard Practice for Establishing Clear Wood Strength Values. ASTM D2555 - 06. West Conshohocken, PA, 19428-2959 USA.

Ayrilmis, N.; Dundar, T.; Kaymakci, A.; Ozdemir, F.; Kwon, J.H. 2014. Mechanical and Thermal Properties of Wood-Plastic Composites Reinforced With Hexagonal Boron Nitride. Polymer composites 35(1): 194-200.

Bourgois, J.; Bartholin, M.C.; Guyonnet, R. 1984. Thermal treatment of wood: analysis of the obtained product. Wood Science and Technology 23(4): 303-310.

DIN 5033. 1982. Colorimetry; measuring conditions for light sources. Germany Standards Service, Beuth Verlag GmbH.

Fufa, S.M.; Jelle, B.P.; Hovde, P.J.; Rørvik, P. M. 2012. Impregnated wooden claddings and the influence of nanoparticles on the weathering performance. Wood Material Science \& Engineering 7(4): 186-195.

Fufa, S.M.; Steen-hansen, A.; Jelle, B.P.; Hovde, P.J. 2013a. Reaction to fire and water vapour resistance performance of treated wood specimens containing $\mathrm{TiO}_{2}$ and clay nanoparticles. Fire and Materials 38(7):717-724.

Fufa, S.M.; Jelle, B.P.; Hovde, P.J. 2013b. Durability, reaction to fire properties, and environmental impact of treated and untreated wooden claddings. Wood Material Science \& Engineering 8(3): 175187.

Hill, C.A.S. 2006. Wood Modification: Chemical, Thermal and Other Processes. $1^{\text {st }}$ ed, John Wiley \& Sons, USA, 25p.

International Organization for Standardization. ISO. 1975. Wood- Determination of moisture content for physical and mechanical tests. ISO 3130, Geneva, Switzerland 
Landry, V., Blanchet, P., Boivin, G. 2013. Metal Oxide Sol-Gels $\left(\mathrm{ZrO}_{2}, \mathrm{AlO}(\mathrm{OH})\right.$, and $\left.\mathrm{SiO}_{2}\right)$ to Improve the Mechanical Performance of Wood Substrates. Journal of Nanoparticles 2013: 1- 8.

Lotfizadeh, H.; Shahverdi, M.; Dashti, H.; Taghiyari, H.R. 2012. Potential usage of nanotechnology in wood drying: treating poplar boards with nanometals affects the drying behavior. Digest Journal of Nanomaterials \& Biostructures 7(4): 1627-1637.

Markova I. 1998. Thermal analysis of chosen wood types. In: Wood structure and Properties, Kurjatko,S., and Kudela, J. (eds.), Arbora Publisher: 121-123.

Matsunaga, H.; Kiguchi, M., Evans, P.D. 2009. Micro distribution of copper-carbonate and iron oxide nanoparticles in treated wood. J Nanopart Res 11:1087-1098.

Nassar, M.M.; Mackay, G.D. 1984. Studies on the Mechanism of Flame Retardation in Wood. Wood Fiber Science 17(4): 439-443.

Poletto, M.; Zattera, A.J.; Fortea, M.M.C.; Santanaa, R.M.C. 2012. Thermal decomposition of wood: Influence of wood components and cellulose crystallite size. Bioresource Technology 109: $148-153$. 73-91.

Robert, T.P.; Chaitanya, K.N. 1990. Synthetic Routes to Boron Nitride. Chemical Reviews 90:

Rosu, D.; Teaca, CA.; Bodirlau, R.; Rosu, L. 2010. FTIR and color change of the modified wood as a result of artificial light irradiation. Journal of Photochemistry and Photobiology B: Biology 99(3): $144-149$.

Rudolph, S. 2000. Boron Nitride (BN). American Ceramic Society Bulletin; 79: 50.

Shebani, A.N.; Van Reenen, A.J.; Meincken, M. 2008. The effect of wood extractives on the thermal stability of different wood species. Thermochimica Acta 471(1-2): 43-50.

Taghiyari, H.R. 2012. Correlation between gas and liquid permeability in some nano silverimpregnated and untreated hardwood. Journal of Tropical Forest Science 24(2): 249-255.

Taghiyari, H.R. 2013. Effects of heat-treatment on permeability of untreated and nanosilverimpregnated native hardwoods. Maderas. Ciencia y tecnología 15(2): 183-194.

Taghiyari, H.R.; Enayati, A.; Gholamiyan, H. 2013. Effects of nano-silver impregnation on brittleness, physical and mechanical properties of heat-treated hardwoods. Wood Sci Technol 47:467480 .

Taghiyari, H.R.; Rassam, G.; Sani, Y.L.; Karimi, A. 2012 Effects of nano-silver impregnation on some mechanical properties of ice-blasted wood specimens. Journal of Tropical Forest Science 24(1): 83-88.

Xanthos, M. 2005. Functional Fillers for Plastics. $1^{\text {st }}$ ed., Wiley-VCH Verlag GmbH \& Co., Germany, 260 p. 